\title{
The Use of pNJ5000 as an Intermediate Vector for the Genetic Manipulation of Agrobacterium Ti-plasmids
}

\author{
By ANGUS G. HEPBURN, JANET WHITE, * LESLIE PEARSON, \\ MARTIN J. MAUNDERS, LORRAINE E. CLARKE, \\ ANDREA G. PRESCOTT AND KEITH S. BLUNDY \\ John Innes Institute, Colney Lane, Norwich NR4 7UH, UK
}

(Received 25 January 1985; revised 24 July 1985)

\begin{abstract}
The use of broad-host-range plasmids derived from RP4 as intermediate vectors for the transfer of narrow-host-range recombinant plasmids from Escherichia coli to Agrobacterium tumefaciens as a preliminary to marker exchange is described. Recombinant plasmids having a ColEl type origin were linked to the RP4 derivative. Cointegrate formation appeared to take place by RecA-independent, homologous recombination within a short piece of DNA derived from the $\beta$-lactamase gene of $\operatorname{Tn} 1 / \operatorname{Tn} 3$ carried by both vector components, so that it never disrupted the recombinant portion of the construction. pNJ5000 provides an unstable intermediate vector for use in marker exchange experiments, while its stable relative $\mathrm{pNJ} 1020$ provides a carrier for use in binary vector systems.
\end{abstract}

\section{INTRODUCTION}

Several descriptions exist of intermediate vectors based on broad-host-range IncP plasmids which can be used to carry modified Ti-plasmid segments, cloned and maintained in Escherichia coli in ColE1 derivatives, into Agrobacterium tumefaciens, where the modification can be transferred to the resident Ti-plasmid by a reciprocal double crossover resulting in a replacement of the wild-type region with the modified region ('homogenotization' or 'marker exchange') (Garfinkel et al., 1981; Matzke \& Chilton, 1981; Ruvkun \& Ausubel, 1981). The IncP plasmid supplies mobilization functions ( $m o b$ ) and an origin of replication (the bom site) since, although ColE1 Mob ${ }^{-}$Bom $^{+}$derivatives (e.g. pBR322: Sutcliffe, 1978; Peden, 1983) can be transferred directly to $A$. tumefaciens by using trans-mobilization (Warren et al., 1978; Comai et al., 1983; Van Haute et al., 1983), they will not replicate in the alternative host. However, trans-mobilization cannot be used with the safer, GMAG/NIH approved vectors pAT153 (Twigg \& Sherratt, 1980), pBR328 and pBR327 (Soberon et al., 1980), all of which have the $\mathrm{Mob}^{-} \mathrm{Bom}^{-}$phenotype. These vectors can be introduced into $A$. tumefaciens by transformation using the freeze-thaw technique of Holsters et al. (1978), but this procedure is inefficient. A conjugative intermediate system has been described which uses a non-conjugative IncW plasmid which, like the $\mathrm{Mob}^{-} \mathrm{Bom}^{+} \mathrm{ColEl}$ derivatives, can be mobilized into $A$. tumefaciens using helper functions supplied by the donor strain, but which has the advantage of being stable in Agrobacterium (Leemans et al., 1981).

Possibly the most serious drawback of using recombinants based on ColE1 is that, given lack of maintenance of such replicons in Agrobacterium, the most frequent event leading to marker recovery is a single crossover which inserts the whole recombinant into the Ti-plasmid, rather than the reciprocal double crossover resulting in incorporation of the modified region (Comai $e t$ al., 1983). While the single crossover event is acceptable for gene insertion (Fraley et al., 1983; Herrera-Estrella et al., 1983), it is of no use for generating deletions of specific regions. Under such circumstances, selecting for the second crossover can be difficult, depending on the selectable markers available. 


\section{A. G. HEPBURN AND OTHERS}

\section{Table 1. Bacterial strains}

\begin{tabular}{|c|c|c|c|}
\hline Species & Strain & Phenotype/genotype & Reference \\
\hline \multirow[t]{4}{*}{ Escherichia coli } & ED8767 & $\sup E$ supF hsdS $\mathrm{Met}^{-} \operatorname{rec} A 56$ & Murray et al. (1977) \\
\hline & W3110 & Thy ${ }^{-}$ & Campbell et al. (1978) \\
\hline & HB 101 & Pro $^{-} \mathrm{Gal}^{-} \operatorname{rps} L$ recAl & Boyer \& Roulland-Dussoix (1969) \\
\hline & UNF510 & $:: \operatorname{Tn} 5$ rpsL $\mathrm{His}^{-} \mathrm{Trp}^{-} \mathrm{Lys}^{-} \mathrm{Lac}^{-}$ & Merrick et al. (1978) \\
\hline \multirow[t]{3}{*}{ Agrobacterium tumefaciens } & C58nal & nal- $100^{*}$ & This paper \\
\hline & T37spec & $s p c-100^{*}$ & This paper \\
\hline & HRR 1 & rif- $100^{*}$ & This paper \\
\hline
\end{tabular}

Table 2. Plasmids and transposons

\begin{tabular}{|c|c|c|c|c|}
\hline \multirow[b]{2}{*}{ Plasmid } & \multirow{2}{*}{$\begin{array}{l}\text { Antibiotic- } \\
\text { resistance } \\
\text { phenotype }\end{array}$} & \multicolumn{2}{|c|}{ Resistance $\left(\mu \mathrm{g} \mathrm{ml}^{-1}\right)$} & \multirow[b]{2}{*}{ Reference } \\
\hline & & E. coli & A. tumefaciens & \\
\hline pBR322 & $\begin{array}{l}\mathrm{Cb} \\
\mathrm{Tc}\end{array}$ & $\begin{array}{r}200 \\
20\end{array}$ & $\begin{array}{r}200 \\
5^{*}\end{array}$ & Sutcliffe (1978) \\
\hline pAT 153 & $\begin{array}{l}\mathrm{Cb} \\
\mathrm{Tc}\end{array}$ & $\begin{array}{r}200 \\
20\end{array}$ & $\begin{array}{r}200 \\
5^{*}\end{array}$ & Twigg \& Sherratt (1980) \\
\hline $\mathrm{pPH} 1 \mathrm{JI}$ & $\begin{array}{l}\mathrm{Ge} \\
\mathrm{Sp} \\
\mathrm{Cm}\end{array}$ & $\begin{array}{l}10 \\
50 \\
20\end{array}$ & $\begin{array}{l}10 \\
50 \\
20\end{array}$ & Hirsch \& Beringer (1984) \\
\hline pKanl & $\begin{array}{l}\mathrm{Cb} \\
\mathrm{Km}\end{array}$ & $\begin{array}{r}200 \\
20\end{array}$ & $\begin{array}{r}200 \\
20\end{array}$ & Pearson (1984) \\
\hline pSZ707 & $\begin{array}{l}\mathrm{Cb} \\
\mathrm{Km}\end{array}$ & $\begin{array}{r}200 \\
20\end{array}$ & $\begin{array}{r}200 \\
20\end{array}$ & This paper \\
\hline pTiT37 & None & & & Sciaky et al. (1978) \\
\hline pTiC58 & None & & & Sciaky et al. (1978) \\
\hline \multicolumn{5}{|c|}{ Transposon } \\
\hline $\begin{array}{l}\operatorname{Tn} 5 \\
\operatorname{Tn} 903\end{array}$ & $\mathrm{Km}$ & 20 & 20 & Rothstein et al. (1980) \\
\hline $\operatorname{Tn} 903$ & $\mathrm{Km}$ & 20 & 20 & Grindley \& Joyce (1980) \\
\hline
\end{tabular}

Where conjugative, stable intermediate vectors have been used, fusion with the T-region recombinant plasmid has been achieved by in vitro recombination, a system which offers only limited flexibility, defined by the restriction maps of the respective components. We therefore sought an alternative system for the formation of an intermediate vector which would still offer a simple selection for marker exchange in Agrobacterium. The core of this system is provided by pNJ5000, a derivative of RP4 which is unstable in RecA ${ }^{+}$hosts (Grinter, 1983).

\section{METHODS}

Bacterial strains and plasmids. These are listed in Tables 1 and 2. E. coli strains were grown at $37^{\circ} \mathrm{C}$ in L-broth containing Difco Bactotryptone $\left(10 \mathrm{gl}^{-1}\right)$, Difco yeast extract $\left(5 \mathrm{gl}^{-1}\right), \mathrm{NaCl}\left(5 \mathrm{gl}^{-1}\right)$, D-glucose $\left(1 \mathrm{~g} \mathrm{l}^{-1}\right)$, or on nutrient agar (Oxoid) if kanamycin selection was to be applied. Agrobacterium strains were grown at $25^{\circ} \mathrm{C}$ in complete medium containing Difco tryptone, Difco yeast extract $\left(5 \mathrm{gl}^{-1}\right),\left(3 \mathrm{gl}^{-1}\right)$.

Mating conditions. Conjugations were done by mixing overnight cultures of bacterial strains in a ratio of $1: 1$, donor : recipient ( $1: 2$ for $E$. coli $\times$ Agrobacterium crosses), and air drying $0.5 \mathrm{ml}$ samples on cellulose nitrate filters $(2.3 \mathrm{~cm}$ diameter). Where at least one of the parents was $A$. tumefaciens, the filters were incubated on complete agar plates at $25^{\circ} \mathrm{C}$ for $1-3 \mathrm{~d}$. When both parents were $E$. coli, the filters were incubated on L-agar at $37^{\circ} \mathrm{C}$ for $15-20 \mathrm{~h}$. After incubation, the bacteria was washed off the filters in water and plated on selective medium at appropriate dilutions. Agrobacterium recipient strains were tested for keto-lactose metabolism according to Bernaerts \& DeLey (1963). 
Selection of tetracycline sensitive cells. Direct selection of tetracycline-sensitive, kanamycin-resistant Agrobacterium cells (cells which had lost the vector but retained the marker for homogenote formation) was done by a modification of the techniques of Bochner et al. (1980) and Maloy \& Nunn (1981). The medium of Maloy \& Nunn (1981) was made containing chlortetracycline $\left(20 \mathrm{mgl}^{-1}\right.$; Sigma), which was then inactivated by autoclaving at $121^{\circ} \mathrm{C}$ for $1 \mathrm{~h}$, fusaric acid $\left(12 \mu \mathrm{g} \mathrm{m}^{-1}\right)$ and zinc chloride $(0 \cdot 1 \mathrm{M})$. This medium greatly enriched for tetracycline-sensitive cells. The addition of kanamycin sulphate $\left(50 \mu \mathrm{g} \mathrm{m}^{-1}\right)$ selected further for these cells which retained the marker for homogenate formation.

Plasmid profiles of Agrobacterium strains. These were examined by analysing small-scale plasmid preparations, made according to Kerr \& Roberts (1972) or Machida \& Ikeda (1983), on $0 \cdot 7 \%$ (w/v) agarose gels as decribed by Meyers et al. (1976). Gels prepared in this manner were treated with $2 \%(\mathrm{v} / \mathrm{v}) \mathrm{HCl}$ for $15 \mathrm{~min}$ and transferred to Genescreen (New England Nuclear) as described by Hepburn et al. (1983a).

Total DNA preparations from A. tumefaciens. Cells from a $48 \mathrm{~h}$ culture $(50 \mathrm{ml})$ were harvested by centrifugation and resuspended in $12 \mathrm{ml} 50 \mathrm{mM}$-Tris/ $\mathrm{HCl}$ ( $\mathrm{pH} \mathrm{8.0),20} \mathrm{mM-EDTA} \mathrm{(=TE8} \mathrm{buffer)} \mathrm{to} \mathrm{which} \mathrm{were} \mathrm{added} \mathrm{SDS}$ $\left(0.01 \%, \mathrm{w} / \mathrm{v}\right.$, final concentration) and predigested Pronase B $\left(400 \mu \mathrm{g} \mathrm{m} \mathrm{m}^{-1}\right.$ final concentration; Calbiochem). The resuspended cells were then lysed at $37^{\circ} \mathrm{C}$ for $1 \mathrm{~h}$. The volume was increased to $50 \mathrm{ml}$ with TE8 buffer and the lysate was extracted once with an equal volume of chloroform : isoamyl alcohol $(24: 1, \mathrm{v} / \mathrm{v})$, and once with an equal volume of phenol saturated with $10 \mathrm{~mm}-\mathrm{Tris} / \mathrm{HCl}(\mathrm{pH} 8 \cdot 0)$ and containing $0 \cdot 1 \%(\mathrm{w} / \mathrm{w}) 8$-hydroxyquinoline. Total nucleic acids were precipitated from the final aqueous phase by treatment with 2 vols ethanol at $-20^{\circ} \mathrm{C}$ for $0.5 \mathrm{~h}$. The crude DNA preparation was purified on $\mathrm{CsCl}$ gradients and stored frozen in $10 \mathrm{mM}-\mathrm{Tris} / \mathrm{HCl}(\mathrm{pH} 8 \cdot 0), 1 \mathrm{mM}$ EDTA.

Recombinant DNA and molecular techniques. The construction of the recombinant plasmids and their analysis by restriction digestion or hybridization were as described by Hepburn et al. $(1983 a, b)$.

\section{RESULTS}

\section{Construction of T-region recombinant plasmids}

The starting points for the marker exchange system are recombinants comprising modified segments of a Ti-plasmid cloned in pBR322 or its Bom- derivatives pAT153 (Twigg \& Sherratt, 1980 ) or pBR327 (Soberon et al., 1980). Since our long term interests lie in the use of the Tiplasmid as a vehicle for modifying higher plants, we have concentrated on Ti-plasmid segments derived from within and around the T-region. Two such clones will be used to show aspects of the system. Other minor variations will be described later.

Tn5 (Rothstein et al., 1980) insertions into the recombinant plasmid pSZ643 (Hepburn et al., $1983 a$ ), which contains HindIII fragments 23 and 31 of pTiC58 (Depicker et al., 1980), were obtained using E. coli strain UNF510 (Merrick et al., 1978) as the Tn5 donor and a single step selection method to isolate the mutant. Cells of UNF510 containing the recombinant plasmid were spread as a lawn on nutrient agar containing kanamycin $\left(15 \mu \mathrm{g} \mathrm{m}^{-1}\right)$, and a drop of kanamycin $\left(5 \mathrm{mg} \mathrm{ml}^{-1}\right)$ was applied to the centre of the plate. Isolated colonies within the cleared zone in the middle of the plate result from $\operatorname{Tn} 5$ insertions into the recombinant plasmid which, as it is present in many copies, confers high level resistance to kanamycin on its hosts. The recombinant plasmid, pSZ643::Tn5-19, carries the transposon approximately 470 bases to the right of the T-region right border (Hepburn et al., 1983a). The BglII/BamHI fragment from Tn5 (1.5 kb of DNA) which contains the neomycin phosphotransferase II (NPTII) gene but not its promoter (Beck et al., 1982) was isolated from agarose gels and cloned into the BamHI site near the middle of the nopaline synthase gene to give pKanl (Fig. 1) (Pearson, 1984).

pSZ707 (Fig. 1) was obtained by ligating the right $1.5 \mathrm{~kb}$ of DNA from HindIII fragment 7 , which lies to the left of the T-DNA left border, to HindIII fragment 33, which lies to the right of the right T-DNA border (Depicker et al., 1980), using pAT153 as the $E$. coli vector. To provide a marker for the eventual homogenotization event, the central PvuII fragment (1.7 kb) of Tn903, which carries the neomycin phosphotransferase I (NPTI) gene encoding kanamycin resistance (Grindley \& Joyce, 1980), was inserted into the HindIII site at the junction of the two Ti-plasmid fragments. Since this cloning eliminates the transposition genes and most of the terminal inverted repeat sequences from $\mathrm{Tn} 903$, this fragment constitutes an immobile marker at the site of the deletion.

Both the recombinant plasmids contain sequences from the nopaline Ti-plasmid pTiC58. pSZ707 contains NPT1 for selection for marker exchange at the site of a large deletion which 

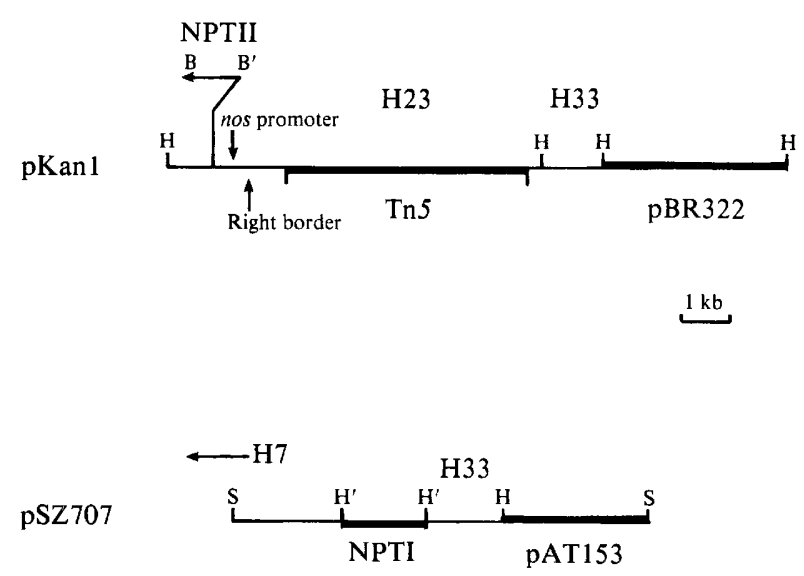

Fig. 1. Restriction endonuclease maps of pSZ707 and pKan1. The major components of the plasmids are indicated. HindIII fragment numbers are taken from Depicker $e$ al. (1980). NPTII is the structural gene for neomycin phosphotransferase II isolated as a BglII/BamHI fragment from Tn5. NPTI is the central Pvull fragment from Tn903 which includes the entire neomycin phosphotransferase I gene. Arrows indicate the positions of the nopaline synthase gene (nos) promoter and the right border of the T-DNA. H, HindIII; B, BamHI; S, SalI; H', a fused HindIII and PvuII site; B', a fused BamHI and $B g /$ II site.

comprises $14 \%$ of its Ti-plasmid parent, while pKanl contains a functional transposon as a selectable marker approximately $1.8 \mathrm{~kb}$ away from a small insertion. One further feature of this latter construction is that the right border of the T-region separates the marker and the DNA insertion.

\section{The intermediate vector and cointegrate formation}

To construct pNJ5000, Grinter (1983) used pRP1, a Tn7 insertion into RP4 (Barth \& Grinter, 1977), as the starting plasmid. PstI digestion of pRP1 and subsequent ligation of the resultant fragments generated pNJ5000, which contains the two major Pst I fragments joined in the normal orientation. pNJ5000 is unstable in a $\operatorname{RecA}^{+}$background but still resistant to tetracycline and conjugative to a wide range of Gram-negative bacterial species (Grinter, 1983).

pNJ5000 was conjugally transferred, with an observed frequency of $1 \%$, to $E$. coli strain ED8767 carrying either pKan 1 or pSZ707. Cointegrates were selected from the population of ED8767, carrying both a recombinant plasmid and pNJ5000, by conjugation into HB101, and were identified using streptomycin and either carbenicillin or kanamycin. Since the ColE1based recombinant plasmids are not self-mobile, transfer of the resistances encoded by these recombinant plasmids indicates mobilization through cointegrate formation. The frequency of transfer of the recombinant markers when related to the frequency of transfer of the tetracycline resistance marker of pNJ5000 indicates a frequency of cointegrate formation of from $10^{-3}$ to $10^{-5}$, and was generally reproducible for a given recombinant plasmid, suggesting that the DNA sequence carried by the recombinant may affect the process.

In all cases, cointegrate formation had taken place between pNJ5000 and the vector component of the recombinant plasmid. Multiple restriction enzyme digestion of cointegrate plasmids isolated by the STET method of Holmes \& Quigley (1981) immediately after cointegrate selection showed the same fragments to be absent in each case, together with the concomitant appearance of an identical fusion fragment. Fig. 2 shows the structure of the cointegrate formed between pKanl and pNJ5000. The fragments of the two component plasmids missing from the cointegrate are both vector fragments. Using several combinations of restriction enzymes, the regions within which recombination had occurred were localized as lying between $0 \mathrm{~kb}(E c o \mathrm{RI})$ and $3.9 \mathrm{~kb}(P s t \mathrm{I})$ on the $\mathrm{pNJ} 5000$ map and between $2066 \mathrm{bp}$ (PvuII) and $3601 \mathrm{bp}\left(P_{s t} \mathrm{I}\right)$ on the pBR322 map. Although dissociation occurs at a significant rate, 


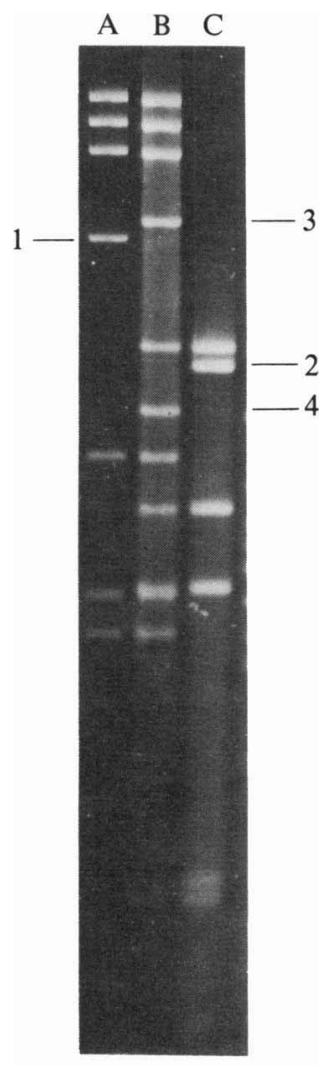

Fig. 2. Regions of cointegrate formation between pKanl and pNJ5000. Plasmid DNA isolated by the STET method was digested by restriction enzymes and fractionated on a $1 \%(\mathrm{w} / \mathrm{v})$ agarose gel in $40 \mathrm{mM}$-Tris, $20 \mathrm{~mm}$-sodium acetate, $1 \mathrm{~mm}$-EDTA at $\mathrm{pH} 8 \cdot 3$. The gel tracks show multiple restriction endonuclease digestion profiles of $\mathrm{pNJ} 5000$ (lane A), pKanl (lane C) and a cointegrate between the two (lane B) obtained using the enzymes SacII, KpnI, BamHI and EcoRI. The DNA fragments present in the parent plasmids but not in the cointegrate (band 1 , lane $A$ and band 2, lane $C$ ) are replaced by two new fragments in the cointegrate (bands 3 and 4, lane B) which represent the digestion products of the DNA around the site of cointegrate formation.

resulting in cells containing both the recombinant plasmid and pNJ5000, the persistence of at least some cointegrate could always be demonstrated by conjugation into a rifampicin-resistant derivative of E. coli ED8767, using suitable antibiotic selection. Again, transfer of carbenicillin resistance demonstrated the presence of the cointegrate.

\section{Transfer to Agrobacterium and marker exchange}

The cointegrate can be mobilized from $E$. coli into $A$. tumefaciens at a frequency of several percent. After transfer, single colonies showing the appropriate resistance phenotypes were analysed to determine their plasmid content and confirm that they contained both the wild-type Ti-plasmid and the cointegrate (Fig. 3, lane F).

The final recombination event between the Ti-plasmid and the cointegrate can be selected in either of two ways depending on the Agrobacterium host strain used. The product of the double reciprocal crossover which replaces wild-type Ti-plasmid sequences by modified sequences will result in the insertion of the homogenate marker (NPTI or NPTII in the examples cited) into the Ti-plasmid. It can then be inherited independently of the markers on the ColE1 and pNJ5000 vector components. Since pNJ5000 is unstable in a RecA+ background, with a rate of loss in the absence of selection of $5 \%$ per generation (Pearson, 1984) after $7 \mathrm{~d}$ of continuous exponential culture, no more than $10 \%$ of the Agrobacterium cells in a liquid culture still carried the cointegrate.

When the host strain is C58, tetracycline sensitive cells can be selected directly in the presence of selection for the kanamycin resistance as described. At least $98 \%$ of colonies selected by this method were tetracycline sensitive. Because selection for tetracycline resistance cannot be used with strain T37, an alternative screening procedure was used. After $7 \mathrm{~d}$ culture in the absence of selection, the cells were conjugated with an E. coli strain carrying pPH1JI (Hirsch \& Beringer, 
(a)
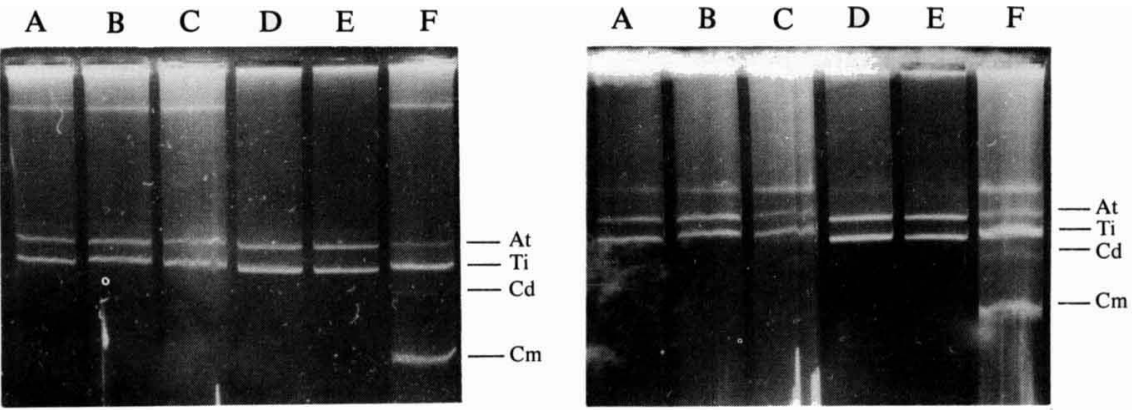

(b)

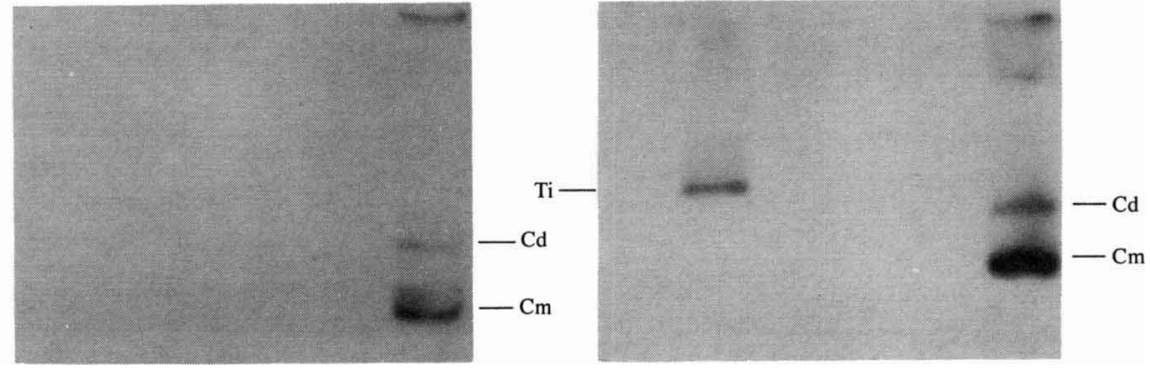

Fig. 3. Plasmids contained by potential modified clones. (a) $0.7 \%(\mathrm{w} / \mathrm{v})$ agarose gel analyses of small scale plasmid preparations from $A$. tumefaciens strains. Lane $\mathrm{F}$ of both panels shows the profile of C58nal containing the cointegrate between pNJ5000 and pKan1 (Cm, monomer; Cd, dimer), pTiC58 (Ti) and the cryptic plasmid pATC58 (At). Lanes A to E show the plasmid contents of possible homogenote clones selected on the basis of their sensitivity to tetracycline. (b) Bands of hybridization obtained when Southern blots of the two gels were probed with a mixture of pNJ5000 and pBR322 (left panel) and pBR322::Tn5 (right panel). The signal in lane $B$ identifies the only true potential homogenate clone where $\operatorname{Tn} 5$ sequences have been retained by the Ti-plasmid but all vector sequences have been lost.

1984). Since pPH1JI encodes gentamicin resistance and is incompatible with pNJ5000, selection for gentamicin resistance, in addition to selection for the Agrobacterium host and the homogenate marker (kanamycin resistance), yields cells where the modified region of the TDNA is maintained in the absence of the cointegrate, presumably following exchange into the resident Ti-Plasmid. The level of spectinomycin resistance in the T37 host is fivefold higher than the level of spectinomycin resistance encoded by pPH1JI, and hence can be used in the cointegrate elimination process. This method can also be used with $A$. tumefaciens strain C58 either instead of or in addition to the selection for tetracycline sensitivity.

Plasmid analyses on colonies showing the correct resistance phenotype confirmed that they did not contain any cointegrate and that no portions of the vector were present in the Tiplasmid. The example in Fig. 3 shows the plasmids of derivatives of a C58 strain which originally carried a pKAN1-pNJ5000 cointegrate after selection for loss of tetracycline resistance. Although none of the samples contain either pBR322 or pNJ5000 sequences (Fig. 3, lanes A-E), only one shows the presence of Tn5 sequences in pTiC58 (Fig. 3, lane B). The presence on the plasmid of the kanamycin resistance used to select reciprocal exchange was shown by demonstrating linked conjugal transfer of the marker and the Ti-plasmid to a strain of Agrobacterium lacking the Ti-plasmid (strain HRR1).

As a final confirmation of marker exchange, total DNA isolated from C58 carrying a possible homogenate was digested with HindIII and EcoRI, fractionated on agarose gels, blotted onto Genescreen and probed with pSZ707. Fig. 4 shows that the Ti-plasmid pTiC58-Z707 has indeed lost the whole of the T-DNA. The frequency of marker exchange was of the order of $10^{-6}$. 

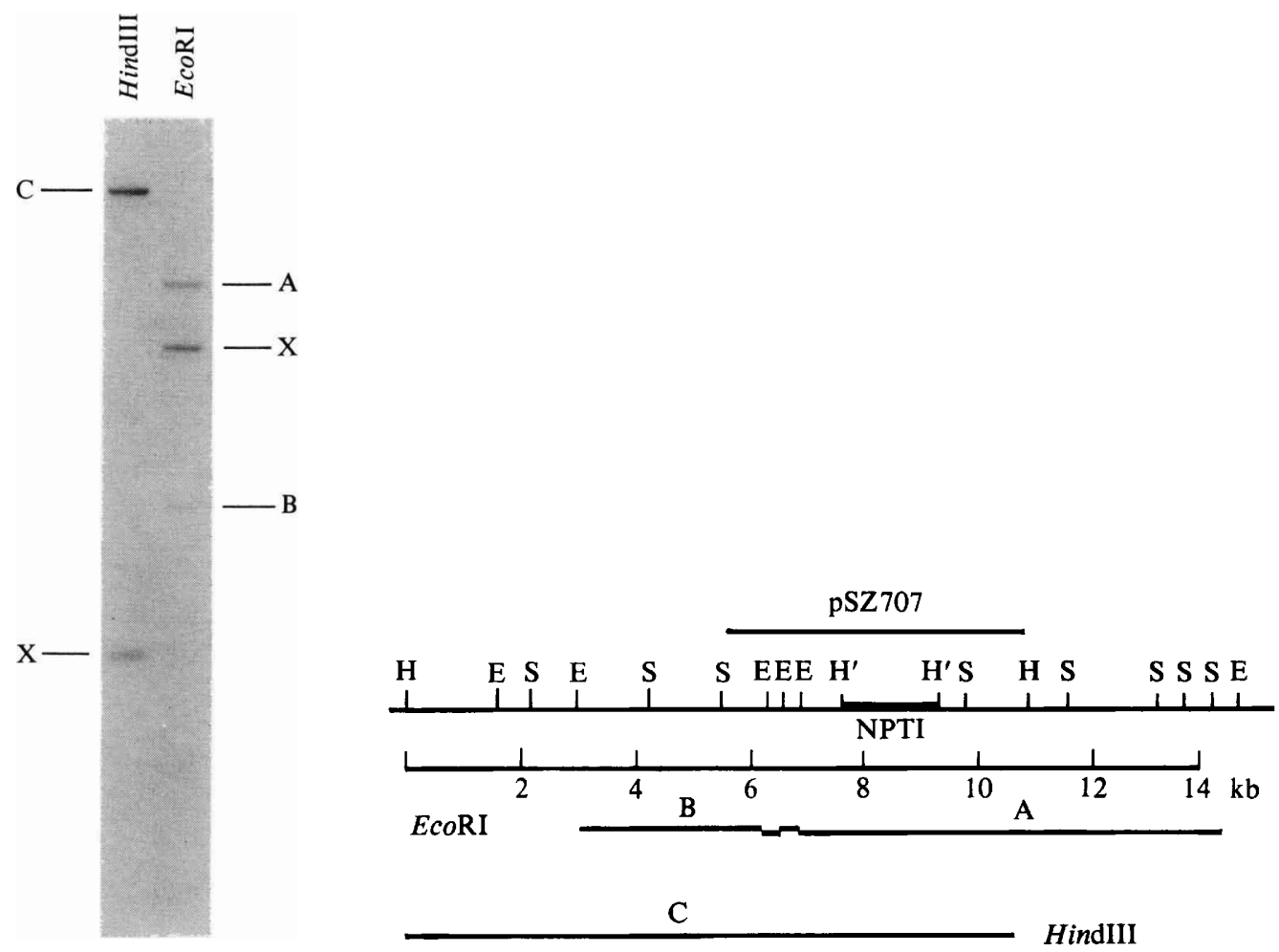

Fig. 4. Predicted map of the modified Ti-plasmid in the region of the deletion. Total DNA from a C58nal strain carrying the plasmid (pTiC58-Z707) was digested with EcoRI or HindIII and the fractionated products hybridized with pSZ707. The major bands predicted from the map (fragments A, $\mathrm{B}$ and $\mathrm{C}$ ) can be seen. The two small EcoRI fragments are not visible on the fractionation shown. The bands marked X show hybridization between the NPTI DNA in the probe and specific fragments of pPH IJI which is also present in the strain. E, EcoRI; H, HindIII; S, SalI ; H', a fused HindIII and PvuII site.

\section{DISCUSSION}

The results presented demonstrate the major features of an intermediate vector based on cointegrate-formation for the modification of Agrobacterium Ti-plasmids. To date, we have only used the system to modify the noplaine-type Ti-plasmids pTiC58 and pTiT37, but given recipient Agrobacterium strains with suitable antibiotic resistance the system should also be applicable to the octopine-type $\mathrm{Ti}$-plasmids. The two examples given demonstrate the use of pNJ5000 in marker exchange experiments. However, we have used pNJ1020, a plasmid related to $\mathrm{pNJ} 5000$, as a vector for the transfer of ColE1-based recombinant plasmids, which constitute one part of a binary system for plant transformation (de Framond et al., 1983; Hoekema et al., 1983). The other part of the binary system is a helper plasmid which has a Ti-plasmid origin of replication and provides the trans-acting vir functions necessary for transformation but has lost all the T-DNA, including the border repeats (pTiC58-Z707). Cointegrates of $\mathrm{pNJ} 1020$ and a recombinant plasmid have been selected as described for pNJ5000 and transferred to Agrobacterium containing a helper plasmid. The recombinant plasmids are required to be stably maintained in Agrobacterium and selection for carbenicillin can be used to counterselect cells in which dissociation has occurred. pNJ1020 contains one more PstI fragment from RP4 than pNJ5000, and this fragment spans map positions $28 \cdot 3-34 \cdot 7 \mathrm{~kb}$ on the RP4/RP1/RK 2 map (Shingler \& Thomas, 1984; N. J. Grinter, personal communication). Why this PstI fragment should confer stability on pNJ1020 is not clear, since it does not encode any of the known maintenance functions (Thomas, 1983; Shingler \& Thomas, 1984). 
The feature which makes the system particularly easy to handle is that the cointegrate formation always takes place between $\mathrm{pNJ} 5000$ and the vector component of the recombinant plasmid. The localization of this event to the specified regions of $\mathrm{pNJ} 5000$ and pBR322 suggests the mechanism for this phenomenon. pBR322 contains 1216 bases derived from the right end of Tn 3 which includes one copy of the terminal inverted repeat together with the whole of the $\beta$ lactamase gene (Sutcliffe, 1978). As a result of its construction, pNJ5000 contains part of TnI (Hedges \& Jacob, 1974) which is present on RP4. As Tn1 and Tn3 are similar (Calos \& Miller, 1980), the two plasmids are likely to have sequences in common. Given the extent of homology between pNJ 5000 and pBR322 we would expect a frequency of recombination between them of $1-5 \%$ in RecA ${ }^{+}$cells (Peterson et al., 1982). As RecA-independent recombination events have been shown to occur at $0 \cdot 1-1.0 \%$ of the frequency of $\operatorname{Rec}^{+}$homologous recombination (Doherty et al., 1983), a RecA-independent recombination frequency between the two plasmids of $10^{-4}-10^{-6}$ would be expected. This agrees fairly well with the observed range of frequency of cointegrate formation of $10^{-3}-10^{-5}$.

In the case of the homogenate obtained using pKan1 (pTiC58-Kan1), the marker for homogenate formation $(\operatorname{Tn} 5)$ is located outside the T-region and, as such, is not transferred to infected plant cells (Pearson, 1984), demonstrating that the foreign gene and the marker for homogenote formation need not be genetically linked through all the stages of the modification and transformation process.

The authors are indebted to Nigel Grinter for providing unpublished results and advice on the structure and use of the pNJ series of RP4 deletion derivatives. L.P. was the recipient of a John Innes Foundation Studentship, M. J. M. of a postdoctoral fellowship from the British Technology Group, L. E. C. of a postdoctoral fellowship from the Cancer Research Campaign and K.S.B. and A.G.P. of AFRC research studentships. The work was done under the conditions laid down by the MAFF plant pests (Great Britain) order 1980 authorized to A.G.H. by licence no. PHF 49/142.

\section{REFERENCES}

BARTH, P. T. \& GRINTER, N. J. (1977). Map of plasmid RP4 derived by insertion of transposon C. Journal of Molecular Biology 113, 455-474.

Beck, E., Ludwig, G., Auerswald, E. A., Reiss, B. \& SCHALler, H. (1982). Nucleotide sequence and exact localization of the neomycin phosphotransferase gene from transposon Tn5. Gene 19, 317-336.

BernaerTs, M. J. \& DeLey, J. (1963). A biochemical test for crown gall bacteria. Nature, London 197, 406 407.

Bochner, B. R., Huang, H.-C., Schienen, G. L. \& Ames, B. N. (1980). Postive selection for loss of tetracycline resistance. Journal of Bacteriology 143, 926-933.

Boyer, H. W. \& Roulland-Dussoix, D. (1969). A complementation analysis of the restriction and modification of DNA in Escherichia coli. Journal of Molecular Biology 41, 459-472.

Calos, M. P. \& Miller, J. H. (1980). Transposable elements. Cell 20, 579-595.

Campbell, J. L., Richardson, C. C. \& Studier, F. W. (1978). Genetic recombination and complementation between bacteriophage T7 and cloned fragments of T7 DNA. Proceedings of the National Academy of Sciences of the United States of America 75, 2276-2280.

Comai, L., Schilling-Cordaro, C., Mergia, A. \& Houck, C. M. (1983). A new technique for genetic engineering of Agrobacterium Ti plasmid. Plasmid 10, $21-30$.

Depicker, A., DeWilde, M., DeVos, G., Van Montagu, M. \& Schell, J. (1980). Molecular cloning of overlapping segments of the nopaline Tiplasmid pTiC 58 as a means to restriction endonuclease mapping. Plasmid 3, 193-211.

Doherty, M. J., Morrison, P. T. \& Kolodner, R. (1983). Genetic recombination of bacterial plasmid DNA. Physical and genetic analysis of the products of plasmid recombination in Escherichia coli. Journal of Molecular Biology 167, 539-560.

Fraley, R. T., Rogers, S. G., Horsch, R. B., Sanders, P. R., Flick, J. S., Adams, S. P., Bittner, M. L., Brand, L. A., Fink, C. L., Fry, J. S., Galluppi, G. R., GoldberG, S. B., Hoffmann, N. L. \& Woo, S. C. (1983). Expression of bacterial genes in plant cells. Proceedings of the National Academy of Sciences of the United States of America 80, 4803-4807.

de Framond, A. J., Barton, K. A. \& Chilton, M.-D. (1983). Mini-Ti: a new vector strategy for plant genetic engineering. Bio/technology 1, 262- 269.

Garfinkel, D. J., Simpson, R. B., Ream, L. W., White, F. F., Gordon, M. P. \& Nester, E. W. (1981). Genetic analysis of crown gall: fine structure map of the T-DNA by site-directed mutagenesis. Cell 27, 143-153.

Grindley, N. D. F. \& Joyce, C. M. (1980). Genetic \& DNA sequence analysis of the kanamycin resistance transposon Tn903. Proceedings of the National Academy of Sciences of the United States of America 77, 7176-7180.

Grinter, N. J. (1983). A broad-host-range cloning vector transposable to various replicons. Gene 21, 133-143. 
Hedges, R. W. \& JaCOB, A. E. (1974). Transposition of ampicillin resistance from RP4 to other replicons. Molecular and General Genetics 132, 31-40.

Hepburn, A. G., Clarke, L. E., Blundy, K. S. \& WHITE, J. (1983a). Nopaline Ti-plasmid, pTiT37, TDNA insertions into a flax genome. Journal of Molecular and Applied Genetics 2, 211-224.

Hepburn, A. G., Clarke, L. E., Pearson, L. \& WhITE, J. (1983b). The role of cytosine methylation in the control of nopaline synthase gene expression in a plant tumor. Journal of Molecular and Applied Genetics 2, 315-329.

Herrera-Estrella, L., Depicker, A., Van Montagu, M. \& SCHELL, J. (1983). Expression of chimaeric genes transferred into plant cells using a Ti-plasmidderived vector. Nature, London 303, 209-213.

HiRsCh, P. R. \& Beringer, J. E. (1984). A physical map of pPHIJI and pJB4JI. Plasmid 12, 139-141.

Hoekema, A., Hirsch, P. R., Hooykaas, P. J. J. \& SCHILPEROORT, R. A. (1983). A binary vector strategy based on separation of vir- and T-region of the Agrobacterium tumefaciens Ti-plasmid. Nature, London 303, 179-180.

Holmes, D. S. \& Quigley, M. (1981). A rapid boiling method for the preparation of bacterial plasmids. Analytical Biochemistry 114, 193-197.

Holsters, M., DeW aele, D., Depicker, A., Messens, E., Van Montagu, M. \& Schell, J. (1978). Transfection and transformation of Agrobacterium tumefaciens. Molecular and General Genetics 163, 181-187.

KERR, A. \& RoberTs, W. P. (1972). Agrobacterium: correlations between and transfer of pathogenicity, octopine and nopaline metabolism and bacteriocin 84 sensitivity. Physiological Plant Pathology 9, 205211.

Leemans, J., Shaw, C, Deblaere, R., De Greve, H., Hernalsteens, J. P., Maes, M., Van Montagu, M. \& SCHELl, J. (1981). Site specific mutagenesis of Agrobacterium Ti plasmids and transfer of genes to plant cells. Journal of Molecular and Applied Genetics 1. 149-164.

MACHIDA, Y. \& IKEDA, J. (1983). Simple method for detection of $\mathrm{Ti}$ plasmid DNA in Agrobacterium tumefaciens. Plant Molecular Biology Reporter 1, 3940 .

MaLoy, S. D. \& NunN, W. D. (1981). Selection for loss of tetracycline resistance by Escherichia coli. Journal of Bacteriology 145, 1110-1112.

MATZKe, A. J. M. \& Chilton, M.-D. (1981). Sitespecific insertion of genes into T-DNA of the Agrobacterium tumor-inducing plasmid: an approach to genetic engineering of higher plant cells. Journal of Molecular and Applied Genetics 1, 39-49.

iMerrick, M., Filser, M., Kennedy, C. \& Dixon, R. (1978). Polarity of mutations induced by insertion of transposons $\operatorname{Tn} 5, \operatorname{Tn} 7$ and $\operatorname{Tn} 10$ into the nif gene cluster of Klebsiella pneumoniae. Molecular and General Genetics 165, 103-111.
Meyers, J. A., Sanchez, D., Elwell, L. P. \& FALKOw, S. (1976). Simple agarose gel electrophoretic method for the identification and characterization of plasmid deoxyribonucleic acid. Journal of Bacteriology 127, 1529-1537.

Murray, N. E., Brammar, W. J. \& Murray, K. (1977). Lambdoid phages that simplify the recovery of in vitro recombinants. Molecular and General Genetics 150, 53-61.

Pearson, L. E. (1984). Gene expression in transformed plant cells. Ph.D thesis, University of East Anglia, UK

Peden, K. W. C. (1983). Revised sequence of the tetracycline-resistance gene of pBR322. Gene 22 , 277-280.

Peterson, B. C., Hashimoto, H. \& Rownd, R. H (1982). Cointegrate formation between homologous plasmids in Escherichia coli. Journal of Bacteriology 151, 1086-1094.

Rothstein, S. J., JoRgensen, R. A., YIN, J. C.-P., YonG-Di, Z., Johnson, R. C. \& REzNIKoFF, W. S. (1980). Genetic organization of Tn5. Cold Spring Harbor Symposia on Quantitative Biology 45, 99-105.

Ruvkun, G. B. \& Ausubel, F. M. (1981). A general method for site-directed mutagenesis in prokaryotes. Nature, London 289, 85-88.

SCIAKY, D., MontoyA, A. L. \& Chilton, M.-D. (1978). Fingerprints of Agrobacterium Ti plasmids. Plasmid 1, 238-253.

ShINGLer, V. \& Thomas, C. M. (1984). Analysis of the $\operatorname{trf} A$ region of broad host-range plasmid RK2 by transposon mutagenesis and identification of polypeptide products. Journal of Molecular Biology 175 , 229-249.

Soberon, X., Covarrubias, L. \& Bolivar, F. (1980). Construction and characterization of new cloning vehicles. IV. Deletion derivatives of pBR322 and pBR328. Gene 9, 287-305.

SutClifFE, J. G. (1978). Complete nucleotide sequence of the Escherichia coli plasmid pBR322. Cold Spring Harbor Symposia on Quantitative Biology 43, 77-90.

Thomas, C. M. (1983). Instability of a high-copynumber mutant of a miniplasmid derived from broad host range IncP plasmid RK2. Plasmid 10, 184-195.

Twigg, A. J. \& Sherratt, D. J. (1980). Transcomplementable copy-number mutants of plasmid ColE1. Nature, London 283, 216-218.

Van Haute, E., Joos, H., Maes, M., Warren, G., Van Montagu, M. \& Schell, J. (1983). Intergeneric transfer and exchange recombination of restriction fragments cloned in pBR322: a novel strategy for the reversed genetics of the Ti-plasmids of Agrobacterium tumefaciens. EMBO Journal 2, 411417.

Warren, G. J., Twigg, A. J. \& Sherratt, D. J. (1978). ColEl plasmid mobility and relaxation complex. Nature, London 274, 259-261. 